\title{
Class Cohesion and Trade-Union Internationalism: Fred Bramley, the British TUC, and the Anglo-Russian Advisory Council
}

\author{
KEVIN MORGAN \\ School of Social Sciences, University of Manchester \\ Oxford Road, Manchester MI3 9PL, UK \\ E-mail: kevin.morgan@manchester.ac.uk
}

\begin{abstract}
A prevailing image of the British trade-union movement is that it was insular and slow-moving. The Anglo-Russian Advisory Council of the mid-I920s is an episode apparently difficult to reconcile with this view. In the absence to date of any fully adequate explanation of its gestation, this article approaches the issue biographically, through the TUC's first full-time secretary, Fred Bramley (I874-1925). Themes emerging strongly from Bramley's longer history as a labour activist are, first, a pronouncedly latitudinarian conception of the Labour movement and, second, a forthright labour internationalism deeply rooted in Bramley's tradeunion experience. In combining these commitments in the form of an inclusive trade-union internationalism, Bramley in 1924-1925 had the indispensable support of the TUC chairman, A.A. Purcell who, like him, was a former organizer in the small but militantly internationalist Furnishing Trades' Association. With Bramley's early death and Purcell's marginalization, the Anglo-Russian Committee was to remain a largely anomalous episode in the interwar history of the TUC.
\end{abstract}

For historians of the international labour movement, Fred Bramley's name registers, if at all, in one connection alone. In 1924-I925 it was with Bramley as its General Secretary that the British Trades Union Congress (TUC) entered into the close association with its Soviet counterpart that, until its break-up in 1927, was to be formalized in the Anglo-Russian Advisory Council (or Anglo-Russian Committee). It is a remarkable phase of British trade-union history, and in its interwar context an anomalous one. In earlier years the TUC had been distinguished by its isolationism. Subsequently, under Walter Citrine, it proved a bulwark of anti-communism within the International Federation of Trade Unions (IFTU). Briefly in between it espoused a notion of international tradeunion unity which it extended to the Soviet Union in conscious defiance of its continental European counterparts. Two British trade unionists were principally instrumental in this process. One was A.A. Purcell, 
successively TUC Chairman and Vice-Chairman in I924-1925. The other was Bramley himself. When in November-December I924 they led a notably well-disposed TUC delegation to Russia, their pro-Soviet sentiments became a matter of international bewilderment and notoriety.

The episode of the Anglo-Russian Committee has been recounted in painstaking detail. ${ }^{\mathrm{I}}$ For historians of communism, it figures prominently in the power struggles that followed Lenin's death. ${ }^{2}$ It has also registered with historians of labour internationalism as the primary expression of the "red temptation" which provoked such discord in the mid-I920s. ${ }^{3}$ On the other hand, it barely figures in standard accounts of British trade unionism and a satisfactory explanation of the phenomenon remains elusive. ${ }^{4} \mathrm{~A}$ byword among many for its insularity, the TUC might least of all have been expected to make an exception for the Bolshevized trade unions with whose intense and tempestuous politicization it had seemingly so little in common. The IFTU secretary Jan Oudegeest, the staunchest of its critics, referred sardonically to the "peculiar form of radicalism" so suddenly manifested in the heartland of reformism. ${ }^{5}$ Contemporary explanations, most forcefully expressed by the secretary of the Labour and Socialist International (LSI) Friedrich Adler, ranged from political naivety and a native theoretical obtuseness to the characteristic double standards of a race of empire-builders. ${ }^{6}$ Whether or not these were preconditions of the British liaison with the Russians, they can hardly explain why it was pursued so energetically in this period only, and at such cost to the TUC's better established connections with both its IFTU partners and the American Federation of Labor. ${ }^{7}$

This article approaches the phenomenon through the lens of biography. Superficially, Bramley and Purcell appear as strikingly different figures: the former an avowed moderate of whom no fellow officer seems to have spoken ill, the latter a rumbustious sometime syndicalist and communist who attracted controversy wherever he went. ${ }^{8}$ Despite these contrasting

I. Daniel F. Calhoun, The United Front: The TUC and the Russians 1923-1928 (Cambridge, I976).

2. For example E.H. Carr, Socialism in One Country, 1924-1926, III (Harmondsworth, 1972 edn), pp. 597-6I7.

3. See Geert van Goethem, The Amsterdam International: The World of the International Federation of Trade Unions (IFTU), 1913-I945 (Aldershot, 2006), chs I-2.

4. For example, Ross M. Martin, TUC: The Growth of a Pressure Group I868-I976 (Oxford, I980) makes no mention of the episode.

5. Jan Oudegeest, "Not the Right Way to Unity", IFTU Press Reports, I October I925.

6. See Friedrich Adler, The Anglo-Russian Report: A Criticism of the Report of the British Trade Union Delegation to Russia from the Point of View of International Socialism (London, 1925).

7. For the latter see Kevin Morgan, Bolshevism, Syndicalism and the General Strike: The Lost Internationalist World of A.A. Purcell (London, 2013), ch. 5.

8. For A.A. Purcell, see ibid. 
personality traits, the reconstruction of their biographies reveals the crucial significance for both of two formative milieux through which they made their way simultaneously. The first was Britain's heterodox pre-war socialist movement, with which both had been associated since the I 890 . The second, more remarkably, was the same, relatively tiny trade union, the National Amalgamated Furnishing Trades' Association (NAFTA), in which Bramley and Purcell had for several years shared responsibilities as full-time trade organizers.

These common features have not previously registered in discussions of the Anglo-Russian Committee, in which biography as a source of insight has figured little. Indeed, while "leftism" of the Purcell type has, in very general terms, been seen as a key to this "peculiar form of radicalism", Bramley has suffered particular neglect as a capable but politically nondescript functionary with barely a trace of a personal history. ${ }^{9}$ This article not only seeks to provide him with one. In doing so, it reveals the existence within the British Labour movement of a distinct if minority strand of inclusive trade-union internationalism which, through Bramley and Purcell, enjoyed a temporary ascendancy within the TUC. It is its central contention that, without this biographical dimension, it is impossible to understand how the TUC in this period only should have become committed to an initiative that sits so incongruously with its reputation for parochialism. $^{10}$

While focusing on the British case, such an argument offers comparative insight into broader discussions of trade-union internationalism. It is a common contention in this literature that the scope for leadership initiative was far greater in international affairs than in respect of the unions' "primary" or domestic field of activity. Jeffrey Harrod referred to leading individuals as in this respect "virtually unencumbered by membership interest or demands", a formulation that has subsequently been

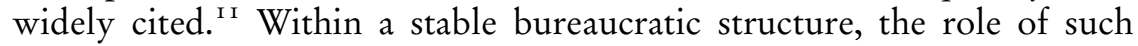
individuals might be constrained or at least obscured by close identification with the institution. In the British case of the I920s, on the other hand, the sheer volatility of TUC policy exposed the role of key actors through changes of personnel. As Bramley and Purcell returned from

9. See Calhoun, United Front, ch. 7, "Epilogue”, in which overall assessment Bramley does not figure.

Io. For which see, for example, Stephen Howe, "Labour and International Affairs", in Duncan Tanner, Pat Thane, and Nick Tiratsoo (eds), Labour's First Century (Cambridge, 2000), pp. II9-I50, I 27.

I I. Jeffrey Harrod, Trade Union Foreign Policy: A Study of British and American Union Activities in Jamaica (New York, 1972), pp. 59-6I; also Susan Milner, The Dilemmas of Internationalism: French Syndicalism and the International Labour Movement 1900-1914 (Oxford, 1990), p. I2; John Logue, Towards a Theory of Trade Union Internationalism (Gothenburg, 1980), pp. I3-14; Van Goethem, Amsterdam International, p. 3. 
Russia, Adler's assistant Oscar Pollak drew a contrast with the "closed ranks" and sense of discipline of the continental labour movements. "For the British movement, with its wide and loose organisation, with its broadness of mind and weakness of theory, with its freedom of individual thought and action, a number of men speak who cannot in themselves represent all its shades or currents of thought", Pollak wrote. ${ }^{\mathrm{I} 2}$ Purcell himself acknowledged the point and, given that the TUC chairmanship was held for just a year, this doubtless increased his determination to make the most of the opportunity. ${ }^{{ }^{3}}$

This should not be confused with what Harrod referred to as the exercise of "individual personality, idiosyncrasy, and caprice". ${ }^{\text {I4 Indeed, it }}$ is precisely as a corrective to such suppositions that a biographical method may be justified. In discussions of the burgeoning new cohort of full-time union officers, of whom Bramley was the first to be employed full-time by the TUC itself, the life-history approach has figured far less often than the stereotype. ${ }^{\text {Is }}$ Characteristic of the latter was Zygmunt Bauman's delineation of a new class of "administrator", displacing the earlier figure of the "agitator", and advancing along anonymous career paths through organizations to which they owed their being. ${ }^{16}$ Contemporary scholarship has rightly urged a greater recognition of the diverse values and expectations which union office-holders "import" into their official roles. ${ }^{17}$ This approach is the more compelling in the case of a formative cohort that could not, pace Bauman, have been generated from within the apparatus itself.

It is not therefore the individual alone that a biographical perspective seeks to recover. Where union office, as in this case, provided only one element in a longer and more varied career, it is the multi-layered complexity of the social, and through it the dense interconnections between different generational cohorts and diverse political, industrial, and other social forms of belief and association. In Robert Taylor's biographically structured history of the TUC, Bramley is passed over almost entirely. Instead, it is Citrine as Bramley's successor who is described as founder of the modern TUC, and the modern TUC in turn as

I 2. Oscar Pollak, "British Labour and the International", New Leader, 23 January i 925.

I3. A.A. Purcell at the 45 th AFL Convention, Report of Proceedings (1925), p. I4O.

I4. Harrod, Trade Union Foreign Policy, pp. 59-6I.

I5. For a fuller discussion see Kevin Morgan, “'Colourless, Dry and Dull': Why British Trade Unionists Lack Biographers and What (If Anything) Should Be Done About It", Journal for the History of Social Movements/Zeitschrift für die Geschichte sozialer Bewegungen, forthcoming, 2013 .

16. Zygmunt Bauman, Between Class and Elite: The Evolution of the British Labour Movement (Manchester, 1972), pp. 192-204.

17. See notably John Kelly and Edmund Heery, Working for the Union: British Trade Union Officers (Cambridge, 1994), ch. 2 and passim. 
Citrine's "personal achievement". ${ }^{8}$ This is consistent with the testimony of Citrine himself, who by his volumes of autobiography and longevity as a witness secured himself precisely the formative role in the TUC's making that he would have wished. ${ }^{19}$ Through the recovery of neglected lives like Bramley's, biography may thus paradoxically provide an antidote to the apotheosis of particular key leadership figures depicted as almost synonymous with the institutions in which they exercised office.

A case like Bramley's is also suggestive of hidden complexities in the attempted extension of the movement's values beyond a purely national framework. In his study of the pre-I9I4 British labour movement, Douglas J. Newton identified a stark distinction between the active internationalism of socialist organizations and the apathy and introversion of trade unionists. ${ }^{20}$ Recent accounts of Labour's emerging international policy have rightly qualified this depiction of the unions. ${ }^{21}$ The point, nevertheless, remains undeveloped at anything but a very general level. Traditional emphases on the Independent Labour Party (ILP) and the largely middle-class Union of Democratic Control (UDC) are accommodated within a broader understanding of Labour's international outlook, but there is little suggestion that their foreign-policy radicalism counted for much even with trade unionists of an international disposition. Paul Bridgen comments of one such union leader, the congenital moderate J.R. Clynes, that "unusually" he was also a member of the ILP. ${ }^{22}$ The picture that remains is one broadly consistent with those theorizations of the labour movement that posit a basic divergence between union pragmatists and socialist intellectuals. ${ }^{23}$

This is the sort of assumption that biography may help to illuminate. Bramley's career not only reveals a certain porosity of boundaries between industrial and political roles. It also demonstrates the sorts of transition that were possible between them. A union officer since before the ILP's formation in I893, Clynes may well have been distinctive in subsequently adopting such an affiliation. Nevertheless, in the quarter of a century or so that followed there was something like a quintupling in the

I8. Robert Taylor, The TUC: From the General Strike to New Unionism (Basingstoke, 2000), pp. ix, 20.

19. For such an account see Marjorie Nicholson, The TUC Overseas: The Roots of Policy (London, 1984).

20. Douglas J. Newton, British Labour, European Socialism and the Struggle for Peace I889-I9I4 (Oxford, I985).

21. See, for example, Rhiannon Vickers, The Labour Party and the World: The Evolution of Labour's Foreign Policy, 1900-195 I (Manchester, 2004), pp. 44-45; Paul Bridgen, The Labour Party and the Politics of War and Peace, 1900-1924 (Woodbridge, 2009), pp. 37-40.

22. Bridgen, Labour Party and the Politics of War and Peace, p. 38, n. 87.

23. As classically expounded in Selig Perlman, A Theory of the Labor Movement (New York, I928). 
number of union officers, including significant numbers who came already bearing such political affiliations. ${ }^{24}$ Indeed, for the working-class activist of socialist outlook, employment by a trade union, or to a lesser extent the cooperative movement, represented the one real opportunity of a full-time commitment that was broadly compatible with goals and values acquired within more overtly political environments. As it progressed from diverse socialist milieux through union office, the existence of such a cohort helps explain the wider phenomenon of the i920s TUC "left".

The paradox, however, was that it was not primarily through exposure to the socialist movement that Bramley's internationalism can be traced. There were, as we shall see, no marked features of transnational interaction in his family background, nor did he travel abroad before I9I4 or speak any other language than English. Rather, it was within his union, the Furnishing Trades' Association, that he encountered a radical conception of internationalism that was unsurpassed by any other British union. It is this that underlines the specificity of his shared socialization with Purcell. The crucial legacy of Bramley's socialist activism was an ethos of latitudinarianism, which the pluralistic culture of British trade unionism then confirmed. This conception of a movement that was at once loyalist and non-schismatic was to find expression in the attempted extension of the ideal of working-class unity to the Bolsheviks. Nevertheless, it was as a trade unionist that Bramley developed a conception of labour internationalism that was distinctly rooted in the unions' most basic values.

To this extent, the presentation here offers some support for John Logue's influential exposition of a distinctive conception of labour internationalism grounded in the economic objects of trade unions. On the other hand, the limitations of Logue's type of analysis will also be apparent. Developing his argument in the context of the post-1945 labour movement, Logue was dismissive of ideological considerations and arguably overly reliant on a short-term rational self-interest model. Articulated at a certain level of abstraction, his arguments took little account of the impact of events, like World War I, which not only impinged on the interests of unions and union members but provoked diverse responses, not necessarily of an internationalist character, that are incomprehensible in terms of selfinterest alone. Logue's emphasis on the dominant role of elites will clearly resonate in a study of a leadership figure like Bramley.

But as we trace this theme biographically, we will also be reminded of the shaping of internationalism as a set of values and explanations to which key cohorts of activists might be more than instrumentally

24. For a discussion, see Ralph Darlington, "British Syndicalism and Trade Union Officialdom", Historical Studies in Industrial Relations, $25 / 26$ (2008), pp. 103-I40, I06-I08. 
committed, and which went beyond the "parasitic elite internationalism" which Logue identified as a sort of leadership perk. ${ }^{25}$ Bramley may not have been a typical figure, whatever that means in such a context. But he does help us see how Oudegeest's "peculiar form of radicalism" not only had a place within the British labour movement, but for a period in the I 920 s even enjoyed a brief ascendancy.

\section{BRADFORD AND THE CLARION VAN}

Fred Bramley was born at Pool near Otley in the West Riding of Yorkshire in September I874. Like most of his peers, he left no substantial record of his personal history and the roots of his socialism remain obscure. ${ }^{26}$ His father, a lay preacher and journeyman engineer, had no recorded political commitments; of Bramley's mother, the name alone has been discovered. Attending the local elementary school, Bramley later described an "uncle", James Murgatroyd of nearby Laisterdyke, as his "early inspiration educationally". ${ }^{27} \mathrm{He}$ was also introduced to the area's vigorous musical traditions, and is said to have been a brass band cornettist. ${ }^{28}$ Having served his time in Bradford, Bramley was admitted to the cabinet-makers' union in I 896 and shortly afterwards married his first wife, Clara Emma Priestley.

It was in Bradford that he made connection with the socialist movement. We have referred to this as a distinct generational experience which helps to locate the TUC radicals of the early i920s. When a Who's Who of British Labour was compiled in I924, trade unionists mostly declined to state their recreations. Nevertheless, responses from within the TUC General Council highlight the supererogatory commitments for which such figures might even now seek to find the time. The Building Workers' secretary George Hicks, a sometime syndicalist, described his sole recreation as "propaganda". The Locomen's leader John Bromley evoked a "spare time" exclusively of Labour and socialist meetings. The Kropotkinian anarchist John Turner spent his "lecturing for societies, etc, of workers too poor to pay fees, on Social, Pol. and Indus. Questions". ${ }^{29}$ Born between I 864 and I 879 , all three had adhered to socialism before the

25. Logue, Toward a Theory of Trade Union Internationalism, pp. 27-29.

26. A small personal collection in the TUC Library Collections at London Metropolitan University relates mainly to the TUC's Russian connections. There is also a biographical file in the TUC archives, University of Warwick Modern Records Centre [hereafter MRC] 292/2 I.I 2/I, and a useful summary entry in Joyce M. Bellamy and John Saville (eds), Dictionary of Labour Biography, IX (Basingstoke, 1993), pp. I6-20.

27. Fred Bramley to Walter Barber, Bradford Trades Hall, I7 March I925, MRC 292/21.I 2/I. The precise family relationship is unclear.

28. Walter Citrine, Men and Work: An Autobiography (London, 1964), p. 75.

29. The Labour Who's Who 1924 (London, 1924). 


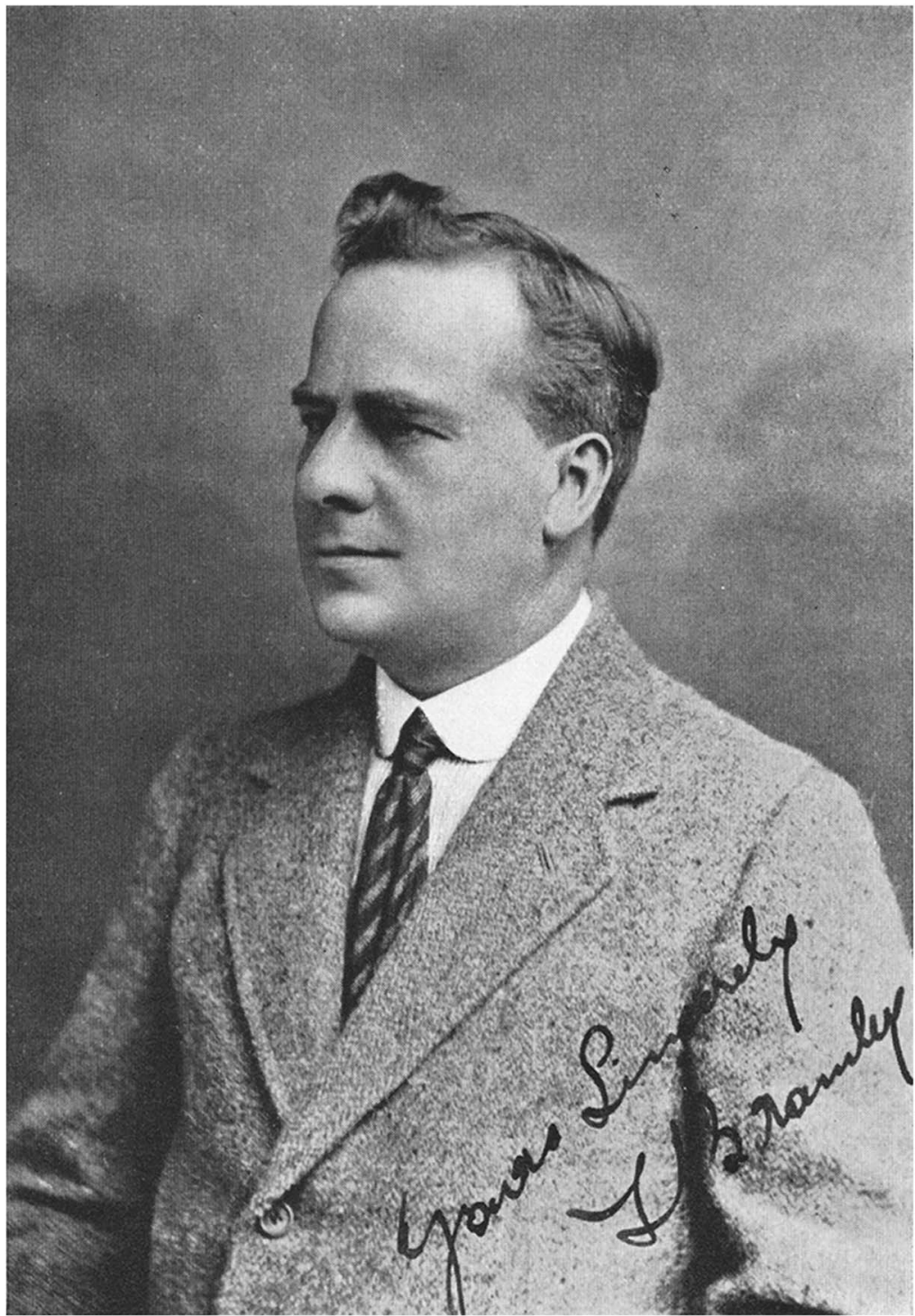

\section{In Memoriam Fred Bramley}

\section{General Secretary, British Trades Union Congress}

Member of General Council, International Federation of Trade Unions who died in Amsterdam, October 10th, 1925

Figure I. Fred Bramley (1874-1925): an official portrait from the I920s, when Bramley was the first full-time Secretary of the British Trades Union Congress. Despite his early death, Bramley played an important role in the development of the modern TUC, though this was quickly overshadowed by that of his successor, Walter Citrine.

Collection IISH 
century's end and taken up union employment between I 898 and I9I4. Between them, they define the scope of a political generation, marked not by homogeneity of outlook - for their partisan commitments were notably disparate - but by the acceptance of difference and the commonality of their political activism. All of them, as it happens, took part in TUC delegations to Russia in I924-1925.

A propensity for outward-looking activism was particularly marked within the furnishing trades. This had been exemplified in an earlier generation by the cabinet-maker and moral-force Chartist William Lovett, who has justifiably been described as the "first working man of modern times with an international outlook". ${ }^{\circ}$ Geographically dispersed and lacking real industrial muscle, furnishing workers were hard put to achieve their most immediate trade interests, let alone the new millenium. ${ }^{3 \mathrm{I}}$ Despite the amalgamation into NAFTA in 1902, the union at its interwar peak had a membership density of just 25 per cent, and in $1924-1925$ it was thirty-fourth in size of the TUC's affiliated unions. Whether industrially, through the trades councils, or through diverse political organizations, all of NAFTA's leading officers were consequently drawn into a wider activist culture marked by weak institutional boundaries. Unlike his colleagues Alex Gossip ("Socialist Sunday School work") and James O'Grady ("Travelling and foreign politics”), Bramley did not record his recreations in the Labour Who's Who. Nevertheless, the fluidity of boundaries was nowhere more apparent than in his home territory of the West Riding of Yorkshire.

It was in Bradford that the ILP famously had its origins in 1893. Melding together an older tradition of industrial activism with the new moral world of the socialists, the party had its principal organizational basis in the trades councils, and in Bradford itself craft unions like Bramley's played a key connecting role in what has been described as a "single homogenous movement". ${ }^{2}$ Bradford's was reputedly the first trades council to adhere to the Labour Representation Committee (LRC), forerunner of the Labour Party, in 1900. ${ }^{33}$ That same year the council's sometime secretary Fred Jowett pushed the Liberals hard as ILP-sponsored candidate in West Bradford. Bramley himself sat briefly on the executives of both the trades council (1899-1900) and the Bradford ILP (1902).

30. Lewis L. Lorwin, Labor and Internationalism (New York, 1929), p. I7.

31. The one published history is Hew Reid, The Furniture Makers: A History of Trade Unionism in the Furniture Trade 1865-1972 (Oxford, 1986).

32. J. Reynolds and K. Laybourn, "The Emergence of the Independent Labour Party in Bradford", International Review of Social History, 20 (1975), pp. 313-346, 337, 345-346; E.P. Thompson, "Homage to Tom Maguire", in Asa Briggs and John Saville (eds), Essays in Labour History (London, 1960), pp. 276-316, 276-279, 3 I6.

33. Bradford Trades Council, Year Book (Bradford, I90I), p. I8. 
One may thus better understand why, in 1925 , he should have described as a continental import the "new and strange habit" of referring to the movement's two "wings". ${ }^{34}$

The story of the Bradford ILP has been somewhat mythologized as that of the Liberals' inexorable displacement by a unified Labour movement uncompromisingly jealous of its independence. ${ }^{35}$ Bramley's experience suggests instead that a powerful impulse to working-class unity had repeatedly come into conflict with more accommodating strategies. His political mentor was the ILP veteran Edward Hartley, who from I 898 sat more or less continuously on Bradford City Council. A butcher by trade, Hartley's business had suffered from his political commitments, and by I 900 he had determined on relinquishing public office to secure his livelihood. Bramley for the ILP was involved in fund-raising efforts to assist him until his business finally collapsed, and the association between them was for several years to be of the closest. ${ }^{36}$

Financial hardship played its part in Hartley's outright rejection of a political carve-up with the Liberals. Relations with the well-established forces of Liberalism were a matter of particular sensitivity and controversy within the infant Labour Party. To some it seemed clear that, without cooperation between the two parties, Labour would long struggle to achieve a significant electoral breakthrough in a system essentially of single-member constituencies. ${ }^{37}$ This approach was epitomized by the secret "MacDonald-Gladstone" electoral pact of 1903, through which Labour in the 1906 election achieved just such a breakthrough, in every case but one without Liberal opposition. ${ }^{38}$ Hartley, however, was among those who upheld the so-called "Fourth Clause" policy of rigorous independence of both of the established parties. ${ }^{39}$ Within a local context, he thus took exception to a Jowett fund extending to Liberal subscribers,

34. Fred Bramley, "Impressions of the Scarborough Trades Union Congress", Labour Magazine, October 1925 , p. 246.

35. Keith Laybourn, "'One of the Little Breezes Blowing across Bradford': The Bradford Independent Labour Party and Trade Unionism c.I890-1914", in idem and David James (eds), "The Rising Sun of Socialism": The Independent Labour Party in the Textile District of the West Riding of Yorkshire between I890 and I9I4 (Bradford, I99I), pp. I-27; for a more nuanced account, David Howell, British Workers and the Independent Labour Party 1888-1906 (Manchester, 1983), pp. 193-199.

36. Molly Jackson, "Edward R. Hartley", I976, West Yorkshire Archives, Bradford [hereafter WYAB] IID85/8/I; Hartley diary entries, 28 August 1900 and I January I90I, WYAB IID $85 / 3 /$ I.

37. There were also some two dozen double-member constituencies (excluding the university seats) which were particularly conducive to some sort of electoral arrangement between the two parties. Bradford, however, was divided into three single-member constituencies.

38. See Frank Bealey and Henry Pelling, Labour and Politics 1900-1906: A History of the Labour Representation Committee (London, I958), chs 6 and I0-II.

39. See, for example, Howell, British Workers and the Independent Labour Party, pp. 209, 283. 


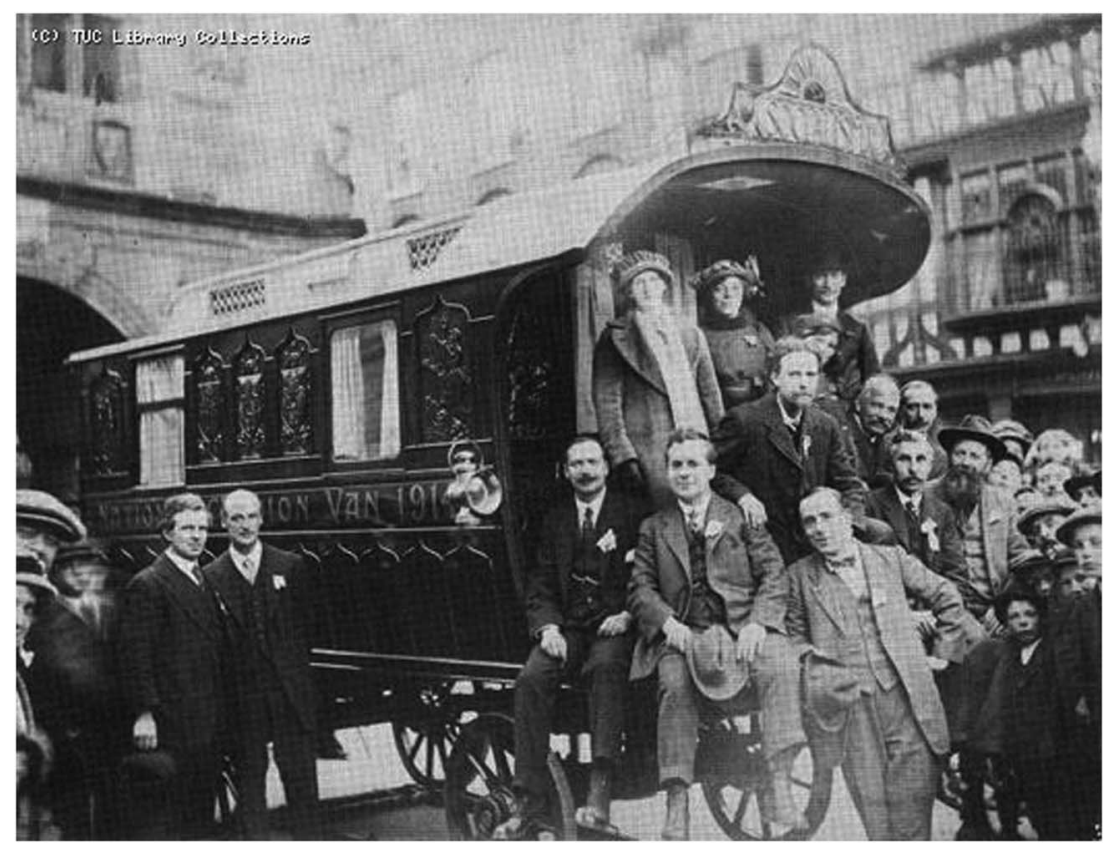

Figure 2. Fred Bramley (seated, holding hat) attending the dedication of the new Clarion van at the Shrewsbury Clarion meet in April I9I4. By this time Bramley's main activities were in his union, but he continued to be remembered as a Clarion stalwart, and the communist Harry Pollitt recalled him also speaking at the York Clarion meet in I9I 2. The bearded figure with his hand on Bramley's shoulder is Edward Hartley, Bramley's political mentor and national Clarion van organizer. The photograph also shows the Birmingham socialist Tom Groom (Clarion secretary) standing in front of the van, second from left. The design for the new van was provided by the well-known socialist artist, Walter Crane.

TUC Library Collections, London Metropolitan University. Used with permission.

and to Jowett's endorsement by professed Liberals like the former trades council secretary Sam Shaftoe. ${ }^{40}$ Apprised of a proposed municipal electoral deal, he fumed that on such a basis he might have got onto the council a good deal earlier and had "a $£_{1,000}$ more to my credit today in good hard cash". ${ }^{\mathrm{I}}$

Both nationally and locally, the ILP was less uncompromising. When a parliamentary vacancy occurred in neighbouring Dewsbury, the party not only hesitated to support Hartley's prospective candidacy but effectively repudiated the candidate of the rival Social Democratic Federation (SDF), Britain's first Marxist grouping and a forerunner of the Communist Party.

40. Edward Hartley diary entries for I6 February and I 2 October I $90 \mathrm{I}$, including unsent letter to Bradford Workers' Committee, WYAB i iD85/3/2.

4I. Hartley diary entries for 16 and I7 October I90I, WYAB I ID85/3/2. 
By now in open revolt, Hartley underlined his defiance by assisting in the re-establishment of an SDF branch in Bradford itself. ${ }^{42}$

Bramley's stance in the affair is not recorded. Nevertheless, Hartley's diaries reveal their close personal and political relationship and Bramley later described the older man as having "for many years [...] played the part of political parent" to him. ${ }^{43}$ At the height of his differences with more compromising colleagues, Hartley was active in Bramley's own unsuccessful municipal campaigns and regarded him as a standard-bearer for independence. ${ }^{44}$ It was just at this time, in October I90I, that Hartley was approached to assist with the missionary-style activities of the Clarion vans. ${ }^{45}$

Also rooted in the industrial north, Robert Blatchford's socialist weekly The Clarion added to the ILP's original fervency a note of easy vernacularity and impatience with internal factional dividing lines. On the other hand, it also supported the Fourth Clause policy, reflecting Blatchford's own strong aversion to Liberalism. The Clarion thus provided a congenial basis for Hartley's own political activity. More importantly, the following year Bramley himself travelled with the van, and from the winter of 1903-1904 he effectively operated under Hartley's aegis as a Clarion fulltimer. ${ }^{46}$ There could have been no better way of getting known within the socialist movement. Though initially Bramley concentrated on the ILP and Clarion heartlands of Lancashire and Yorkshire, by 1907 he had carried out winter campaigns in Scotland and the English Midlands as well as an inaugural summer tour of the London district. "He was always a good speaker", Hartley beamed paternalistically, "but three years with the vans has made him one of our best". ${ }^{77}$

Rather than inculcate a particular institutional loyalty, this if anything attenuated it. In the absence of any single mass workers' party, as in Germany or Belgium, activists in Britain's socialist bodies were sparsely

42. Martin Crick, "Labour Alliance or Socialist Unity? The Independent Labour Party in the Heavy Woollen Areas of West Yorkshire, c.1893-1902", in Laybourn and James, "The Rising Sun of Socialism", pp. 28-44, 38-41; Howell, British Workers and the Independent Labour Party, pp. 200-201; Bealey and Pelling, Labour and Politics, pp. I65-166; Laurence Thompson, The Enthusiasts: A Biography of John and Katharine Bruce Glasier (London, 1971), pp. I24-I28, citing J. Bruce Glasier.

43. The Clarion, 27 January 1905 .

44. Edward Hartley diary entry for 23 November I 901 , WYAB I ID85/3/2. Both in I 901 and in a by-election in 1902 Fred Bramley came in last in the North Bierley ward.

45. Hartley diary entry for Is October I90I, WYAB i ID85/3/2; also Hartley's recollection, The Clarion, is July i 904.

46. According to a profile in the Bradford Weekly Telegraph, I2 September I9I3 (WYAB I ID $8 / 2 /$ I), Hartley had spent two years as paid secretary to the mission, and he afterwards made a living by journalism, recitals, and elocution lessons.

47. The Clarion, 9 November 1906 (Hartley). 
spread, unevenly distributed, loosely disciplined and inclined to mutual support in the interests of comradeship and critical mass. Bitter as were the institutional rivalries at national leadership level, The Clarion was not a party organ and demonstratively had no part in them. The peripatetic Clarion lecturers in any case relied on whatever local support was available, of any affiliation or of none, and Bramley willingly shared platforms with the SDF, the ILP, and preferably both. Grist to the Clarionettes' mill was when the experience of cooperation brought about a permanent "amalgamation of forces". ${ }^{8}$ Anathema, on the other hand, was the sight of diverse socialist bodies trading personal and factional abuse. ${ }^{49}$ Symptomatically the Bradford ILP Speakers' List urged sales of both The Clarion and the SDF weekly Justice as well as the ILP's Labour Leader. ${ }^{50}$

Though acknowledging Hartley as a father figure, Bramley had an instinct either of ILP loyalism or of career interest that his mentor lacked. ${ }^{51}$ Though as yet combining ILP and SDF affiliations, Hartley's discontentedness was advertised annually when he stood in the elections for ILP national Chairman and Secretary. Relations deteriorated irreparably when in I90s he came forward as an SDF parliamentary candidate in Bradford East, in open disregard of Jowett's interest in a Liberal abstention in the adjacent western division. It was thus paradoxically beholden to Hartley that in the 1906 general election, somewhat against his own initial inclinations, Jowett achieved Labour's one parliamentary success against both Liberal and Conservative opposition. ${ }^{52}$ Though ILP leaders alleged peevishness and personal vanity, ${ }^{33}$ Blatchford reaffirmed the principle of socialist unity as exemplified by his employment of Hartley as The Clarion's van manager and Jowett as its ILP correspondent. As if anticipating the slogans of the I920s, he even called for a "united front to the enemy" as well as the avoidance of personalities. "Let the men go into the ring and punch one another with good humour and good understanding", he commented with his customary bonhomie, "[and] we shall soon cease to hear about Socialist splits". 54

Bramley was to honour this precept amidst splits far more consequential and vitriolic. More immediately, he readily spoke in support of

48. See, e.g., The Clarion, io February 1905, 23 March 1906, and is June 1906.

49. See his comments on the London suburb of Tottenham, The Clarion, 3 I August 1906.

50. Undated Speakers' List, British Library of Political and Economic Science [hereafter BLPES] ILP/9/ז8.

5. For Bramley's description of Hartley as his "political father" see The Clarion, i I August 1905 .

52. Compare with Laybourn, “'One of the Little Breezes Blowing across Bradford”, where this is described as if representing the unwillingness of the ILP itself to reach an understanding with local Liberals.

53. Keir Hardie to R.B. Cunninghame Graham, 4 January 1906, BLPES ILP 4/1906.

54. Robert Blatchford to Keir Hardie, 30 March 1905 and n.d. but similar, BLPES ILP/4/1905. 
the Clarion vanner and SDF parliamentary candidate in Aberdeen North, Tom Kennedy. 55 Bramley was also one of the "Bradford Moor boys" who pointedly selected Hartley as an ILP municipal candidate even as he maintained his parliamentary candidacy for a rival body. ${ }^{56}$ Nevertheless, Bramley had parliamentary ambitions of his own, and for the first time he now implied an unwillingness to be regarded as Hartley's protégé. ${ }^{57}$ When a Salford contingent of Clarion supporters sought an electoral champion in circumstances very much like those in Bradford, Bramley, unlike his mentor, demurred both as a "Trade Unionist of ro years standing" and as an ILP member who wanted to remain "a loyal member". ${ }^{8}$ Bramley's tolerance of different views of socialism was to be evident throughout his career. Had he not combined it with this sense of loyalty, it is most unlikely that he would have attained so influential a position from which to give effect to it.

Declining hopeless prospects elsewhere, Bramley had to wait until the South Aberdeen by-election of February 1907 for his first parliamentary candidacy. Given the strong SDF presence in the city, some members of the local ILP saw an officially sanctioned candidate as a way of "getting Aberdeen into line" with the national movement. ${ }^{59}$ Bramley's campaign was nevertheless conducted in the Clarion spirit. His agent was in the ILP, his "right-hand man", Kennedy, in the SDF and his campaign further enlivened by Suffragette supporters returning the support and solidarity he had shown their cause as a Clarion lecturer. ${ }^{60}$ Back in Yorkshire, according to Philip Snowden, Bramley had been steered away from Marx and urged to emulate Snowden's own "Come to Jesus" perorations. ${ }^{61}$ In Scotland, on the other hand, his agent warned that they "took their politics very seriously" and expected more than "Clarion Van propaganda lectures". ${ }^{62}$ Always destined for defeat, Bramley nevertheless drew the positive moral of

55. The Clarion, 8 December 1905 .

56. The Clarion, 28 July 1905. Edward Hartley had been temporarily ineligible to stand in 1903, having moved beyond the city's borders.

57. The Clarion, 28 July and 4 August 1905; also 3 November 1905 for Fred Bramley's parliamentary ambitions.

58. C.E. Fraser to J. Bruce Glasier, ro December 1905, University of Liverpool Archives [hereafter ULA] GP I/I/732; Glasier diary entry for 27 December 1905, ULA GP 2/I/I2; Bealey and Pelling, Labour and Politics 1900-1906, pp. 246-247, 26I-262.

59. J. Duncan to Keir Hardie, 7 January 1907, BLPES ILP/4/1906/438.

60. See Sylvia Pankhurst, The Suffragette: The History of the Women's Militant Suffrage Movement (New York, I9 I I), p. I46; also Hannah Mitchell, The Hard Way Up (London, I984 edn), pp. II9-I20, I3I. Fred Bramley had previously shared platforms with figures like Mrs Pankhurst, Teresa Billington, and Ethel Annakin (later Snowden), and during the war he was to chair Sylvia Pankhurst's Adult Suffrage Joint Committee.

6r. Philip Snowden, An Autobiography (London, I934), p. 82.

62. J. Duncan to Keir Hardie, 7 January 1907; J. Duncan to Ramsay MacDonald, 22 February 1907, University of Manchester Special Collections [hereafter UMSC] RMD I/2/6. 
“Trade Unionists, SDFers, ILPers and the Women's Political Union [...] fighting shoulder to shoulder" ${ }^{63}$ Among Labour's emerging political class, the most obvious parallel is with the similar generosity of spirit of George Lansbury, which Lansbury too was to extend with seeming indiscriminateness to the Bolsheviks. ${ }^{64}$

Bramley's own parliamentary prospects were suddenly closed off for reasons that had nothing to do with considerations of faction. The peripatetic lifestyle of the labour agitator could mean strained domestic relations and the compensating comforts of the tap-room. If Bramley as a teetotaller avoided the latter, his speaking activities were now abruptly halted by the threatened exposure by a Partick socialist of Bramley's "dishonourable conduct" towards his wife. ${ }^{65}$ Socialists were at this time more than usually defensive regarding such allegations, in part because of the controversy occasioned by H.G. Wells's Socialism and the Family (1906). ${ }^{66}$ If Bramley avoided public scandal, it was evidently on condition that he withdraw from public activity. His name disappeared overnight from The Clarion, and not even Hartley offered an explanation. As divorce proceedings took their course, Bramley and his second wife began a new life in London. It was thus that he returned to his trade and resumed his activities within NAFTA. When parliamentary salaries were introduced by the Asquith government, it was Bramley who at the start of I9I2 filled the vacancy for trade organizer left by the NAFTA MP O'Grady. Already aged thirty-seven, it is no surprise that he should have "imported" some element of radicalism into his new union career. What could not have been anticipated was that this should most of all have been expressed in respect of labour's international aims.

\section{INTERNATIONALISM AND THE COMMON RULE}

On his death in I925, Bramley's colleague Alonzo Swales recalled how in the summer of r9I4 he had warned of all that militarism meant "in blood and tears and suffering". ${ }^{67}$ No socialist agitator could have been

63. The Clarion, is February 1907.

64. The best of Lansbury's several biographies is John Shepherd, George Lansbury: At the Heart of Old Labour (Oxford, 2002). For his pro-Bolshevik proclivities, see Kevin Morgan, Labour Legends and Russian Gold: Bolshevism and the British Left, Part I (London, 2006), ch. 5 .

65. J. Bruce Glasier to Ramsay MacDonald, i7 February 1907, UMSC RMD i/2/5; J. Duncan to Ramsay MacDonald, I8 February 1907, Labour History Archive and Study Centre, Manchester, GC I2/79; also Blackburn Times, I2 March 1904, for Bramley's teetotalism.

66. Karen Hunt, Equivocal Feminists: The Social Democratic Federation and the Woman Question I884-I9II (Cambridge, I996), ch. 4.

67. Alonzo Swales, "Fred Bramley: Remembrances and an Appreciation", Labour Magazine, November 1925 , p. 315 . 
unfamiliar with such language, and at the ILP's annual conference it was part of the routine business to pass an anti-militarist resolution with either little or no dissent. ${ }^{68}$ There is nevertheless little evidence of these concerns in Bramley's Clarion van reports. His advertised lecture topics indicate generic exposition of the socialist credo, with specific points of reference like poverty, unemployment, and individualism, but none such as militarism or empire that might have attested his internationalism. ${ }^{69}$ When he was confronted with "imperialist sentiment" in Birmingham, he did not so much seek to dispel it as identify "national supremacy" with the "moral, mental, and physical vitality of the people".$^{0}$ The Chamberlainite social imperialism that was hegemonic in the city would not have felt much threatened by this. Perhaps there was something here too of the Clarion spirit, with its Blatchfordian accent of "Britain for the British", which in Blatchford's case was taken to the point of outright chauvinism. ${ }^{71}$ There is no evidence that Bramley ever went so far. It is nevertheless telling that during his election campaign he should have spurned discussion of the Eastern question in favour of "the South Aberdeen question". ${ }^{2}$

The unions were not the source of this parochialism. Perhaps they were even the antidote to it. At another election meeting, Bramley found himself challenged as an Englishman in a Scottish constituency. Leaving aside his well-worn socialist precepts, he responded by presenting his credentials as a longstanding trade unionist and "the representative of the trade unionists of Great Britain". As he then flourished his NAFTA card, scenes ensued "of the wildest enthusiasm, the whole audience assuming a standing position and cheering lustily". ${ }^{73}$ Though the context was a British one, the logic of such a position was potentially illimitable. This notion of a union interest transcending local particularities was the keystone of a conception of labour internationalism to which British trade unionists had already lent their voices at the time of the First International. ${ }^{74}$ It was an outlook strongly expressed within the Furnishing Trades, and Bramley was to emerge as one of its most forthright exponents.

68. Paul Ward, Red Flag and Union Jack: Englishness. Patriotism and the British Left, I88I-I924 (Woodbridge, I998), pp. I I3-I I 8.

69. See the twelve possible topics advertised in The Clarion, 27 October i905.

70. The Clarion, 23 November 1906.

71. Robert Blatchford's Britain for the British was published in London, 1902. On this point see Bernard Semmel, Imperialism and Social Reform: English Social-Imperial Thought I895-1914 (Cambridge, MA, I960), pp. 222-233; Ward, Red Flag and Union Jack, pp. 51-54. 72. Aberdeen Free Press, I6 February 1907.

73. Aberdeen Free Press, I 8 February 1907.

74. G.M. Stekloff, Eden and Cedar Paul (trans.), History of the First International (London, 1927), p. I4, cited Theodore Rothstein: "it was precisely in England that the proletariat did not merely develop the keenest sense of its solidarity with its foreign brethren, but also became aware how essential to success [...] was a co-ordination of effort based on this solidarity". 
Bramley's understanding of trade-union objects is documented both in his union journal and in the wider Labour press. By the middle war years he was somewhat unusual in moving in Fabian circles, most notably a group including the Webbs and G.D.H. Cole that met some half a dozen times to discuss postwar trade-union prospects. ${ }^{75}$ In his own pronouncements on such matters, Bramley showed familiarity with the Webbs' writing in particular. He thus advocated craft-based organization in a Webbian spirit of vocationalism and the interdependency of democracies of citizens, producers, and consumers. Both themes featured prominently in the contemporaneous writings of the Webbs, and Bramley as a staunch cooperator even held that cooperation offered greater prospects for the dissolution of capitalism than "trade union efforts to increase wages". ${ }^{6}$ The Webbs, on the other hand, made no significant contribution to the discussion of labour internationalism. In their magnum opus Industrial Democracy, compendious as it is, the discussion of international competition was at once perfunctory, dismissive, and oblivious to the possible implications for a wider conception of workers' solidarity. ${ }^{77}$ If British trade unionists could appear parochial, they were certainly not more so than some of those who sought to guide them. On the other hand, with the development of markets both nationally and internationally, and the challenge thus posed to trade unionists of movements of capital, labour, and commodities, the underlying logic of the Webbs' exposition did not have to be confined within national borders.

Bramley held, uncontroversially, that the primary object of trade unions was control of the labour supply, whether exercised directly, or through regulating the distribution of the goods and services in which this labour was expressed. ${ }^{78}$ In the exercising of such control the Webbs had ultimately identified two basic "devices" available to organized labour, namely the Common Rule and the Restriction of Numbers. ${ }^{79}$ Whether at a national or an international level, there were complex relations between this "Common Rule", to be achieved by collective organization, and the Restriction of Numbers through exclusion. There was certainly no simple equivalence between these levels, and beyond the national basis on which

75. Beatrice Webb diaries, entries for 13 December 1916 and 6 March 1917, BLPES Passfield papers; also Fred Bramley in Fabian News, November 1916, p. 45 .

76. Relevant texts by Sidney and Beatrice Webb include: A Constitution for the Socialist Commonwealth of Great Britain (London, 1920), and The Consumers' Cooperative Movement (London, 192I). For the connections with Bramley and relevant citations, see Kevin Morgan, The Webbs and Soviet Communism: Bolshevism and the British Left, Part 2 (London, 2006), pp. 103-104, 223-224.

77. Sidney and Beatrice Webb, Industrial Democracy (London, I920 edn), pp. 74I-745 and passim.

78. NAFTA Monthly Report, March i916, p. i I.

79. Webb and Webb, Industrial Democracy, pp. 560-56r. 
unions were organized as sovereign bodies the balance tended to shift from the Common Rule of labour internationalism to the more restrictive positions of labour protectionism. Eric Hobsbawm refers to the multidimensionality of the trade unionist, who was never only a trade unionist, and was thus susceptible to wider influences of nationality or ethnicity. ${ }^{80}$ In counteracting these influences, doubtless Bramley's conversancy with socialist argument was indispensable. Even so, analogous tensions existed at national and international levels, and in purely economic terms the differences were of degree rather than kind.

Much was to be made in the I920s of the distinction between "sheltered" trades and industries exposed to foreign competition. From a trade unionist's perspective, however, industries as incompletely organized as furnishing were anything but sheltered, even at home. Production was tied neither to the locality in which it was required, nor to natural resources, nor to any great investment in plant or site development. In the absence of national bargaining structures, the key issue facing NAFTA was therefore that of "cheap labour districts" as a source both of industrial undercutting and of strike-breaking labour. ${ }^{8 \mathrm{I}}$ Visiting his native Bristol in I909, O'Grady described how in Germany, France, and Belgium he had never encountered such conditions of work and labour organization as in Bristol's "evil crop of sweat dens". The "bogey of foreign competition", he concluded, was not the issue, it was Bristol itself. ${ }^{82}$ Though he was also influenced by the Ruskin-Morris tradition, apprehension of transferability within a competitive labour market helped reinforce Bramley's deep attachment to a craft-union principle uniting furnishing workers, no matter where they were employed. ${ }^{83}$

Centrifugal pressures were particularly evident in the London region for which Bramley was responsible as NAFTA organizer. Within the metropolis, growth of the sweated trade in peripheral districts gave rise to what Bramley described as the "City Road border line" between east and west. ${ }^{8}$ Beyond it, but within easy reach, the Home Counties woodworking town of High Wycombe was "one of the most dangerous centres of cheap labour in the country" and a direct threat to the better-organized London branches. Bramley was no syndicalist and in taking up his duties

80. Eric Hobsbawm, "Working-Class Internationalism", in Fritz van Holthoon and Marcel van der Linden (eds), Internationalism in the Labour Movement I830-1940 (Leiden, I988), I, pp. 3-16, 9, I4.

8I. See Fred Bramley, NAFTA Monthly Report, June i913, where he notes how these districts were developed "in the immediate neighbourhood of the large centres where we have been most successful in securing an increase of wages".

82. NAFTA Monthly Report, September 1909, pp. 8-9.

83. See Fred Bramley, "Craft Versus Industrial Unions", Labour Year Book (London, I9I6), pp. I $84-186$.

84. Fred Bramley, NAFTA Monthly Report, September i9i6, p. i I and October i9i6, p. i 2. 
with the issue looming he described his "primary duty and difficulty" as that of heading off premature action. ${ }^{85}$ If he thus observed the Fabian precept of waiting patiently, he did not however overlook its neglected corollary, to "strike hard" when the opportunity arrived. In November I9I3, NAFTA's attempt to extend its presence in the town was met by a thirteen-week employers' lockout, assisted by a large imported police presence accused by the union of employing unprecedented degrees of brutality. Leading on the spot, Bramley not only brought the dispute to a successful conclusion but put together an "Anti-Violence Brigade" of unabashedly combative disposition. ${ }^{86}$ Though the union had won a famous victory, the underlying problem remained. "It therefore competes against every town", Purcell wrote once more of High Wycombe a few years later. "Strengthen it and correspondingly we strengthen every other centre." ${ }^{\prime 7}$

The analogy with trade-union internationalism was reinforced in NAFTA's case by the interplay of ethnic as well as geographical factors in the shaping of the labour market. Reflecting on the insularity of the British worker, the US labour economist Lewis L. Lorwin sought explanation in the low levels of inward and outward movement across Britain's national borders as well as diverse linguistic and psychological factors. ${ }^{88}$ With its ethnically diverse membership, including significant numbers of Jewish workers of east European origin, NAFTA's espousal of internationalism might seem the exception confirming that general rule. Even so, a solidaristic response to such a challenge was anything but guaranteed. Trades in which such labour could be depicted as a source of cheap competition were among those likeliest to support the provisions of anti-alien legislation, and such sentiments were certainly expressed within NAFTA. ${ }^{89}$ Despite his membership of the SDF, O'Grady has been particularly associated with such views, and even Bramley on at least one occasion resorted to the image of the conniving Jew. ${ }^{90}$

There was, however, an important distinction; for while O'Grady's primary concern was with cheap Jewish labour, Bramley's was directed at a Jewish employer whose "indentured slaves" of local origin had signed away their "much boasted British liberty". Accused of anti-Jewish prejudice, Bramley therefore reaffirmed the principle of "no distinction of race,

85. NAFTA Monthly Report, March 1912, pp. 9-10.

86. NAFTA Monthly Report, January I9I4, pp. I2-I ; February 19I4, pp. 9-Io; March 19I4, p. 8; also Reid, Furniture Makers, ch. 4.

87. NAFTA Monthly Report, May 1919, p. I4 and December I919, p. is.

88. Lorwin, Labor and Internationalism, pp. II $3-\mathrm{II} 4,4 \mathrm{I} \mathrm{I}-4 \mathrm{I} 3$.

89. Ward, Red Flag and Union Jack, pp. 54-58; also Arthur Eades (NAFTA Birmingham branch) to Keir Hardie, 9 May 1905, BLPES ILP/4 I905/59.

90. NAFTA Monthly Report, May I9I3, pp. 9-10; for O’Grady see, e.g., Joseph Buckman, Immigration in the Class Struggle: The Jewish Immigrant in Leeds I880-19I4 (Manchester, 1983), p. 167. 
colour, or creed", which paradoxically was reinforced by the example of employers putting their own unnegotiable class interests above such secondary differences..$^{91}$ In just this way, Gossip described the industry's employers' association as one of "Jew and Gentile, joining hands together to sweat the life-blood out of the worker, while whining about each other behind each other's backs". ${ }^{2}$ Even without leaving his own shores, Bramley was thus already conversant with the nationalities question:

I have met the Jew and the Gentile, the Frenchman and the German, the Dutchman and the Briton [...]. To all of them my mission has been the same, to ask them to pay something and 'tis true, wonderfully true, that where interests are identical, racial sentiments, or religious feeling, makes no difference. An employer is the same person every time, they buy labour like wood, in the cheapest market $[\ldots] .{ }^{93}$

The moral was one of class cohesion. It was a theme to which Bramley would shortly return in the context of European war.

\section{CLASS COHESION AND SPURIOUS PATRIOTISM}

While war had yet to be declared, socialists both individually and collectively had spelt out what it meant in blood and suffering. Following its declaration, how many of them then spelt out the greater costs of not fighting? Blatchford, of course, was among them, while Hartley and O'Grady were to make their way into H.M. Hyndman's bellicose National Socialist Party. In the words of F.L. Carsten, it was the ILP alone that "saved the honour of the International". ${ }^{94}$

Bramley at the time had also described the ILP as having saved the labour movement from "complete disgrace". 95 His position at the very outbreak of the war is unclear from NAFTA sources, and it is possible that he was constrained by the need to secure re-election as trade organizer at the end of I9I4. Once this was achieved, however, he joined with his General Secretary Gossip in presenting an unambiguous condemnation of the war for the approval of NAFTA members in March i9is:

Today, millions of Trade Unionists face each other [...] armed to the teeth with the most hellish instruments of destruction human ingenuity can devise. It is not $[\ldots]$ a question at present as to whether the rulers of our own country, or the

91. NAFTA Monthly Report, June 1913, p. i I.

92. NAFTA Monthly Report, June i91 2, p. 2.

93. NAFTA Monthly Report, October i 9i 2, p. 9.

94. F.L. Carsten, War Against War: British and German Movements in the First World War (London, I982), p. 26.

95. Fred Bramley, Class Cohesion versus Spurious Patriotism: A Straight Talk to British Workers (Manchester, n.d. but I9I5), p. 9. 
rulers of another, are most to blame. If the curse of Militarism is more prevalent in Germany than at home $[\ldots]$ there is all the more reason that we should, with greater freedom, use the power of organised labour to promote a clearer vision, and attempt to build up a universal desire for peace and goodwill strong enough to prevent such crimes as at present are being committed on humanity $[\ldots]]^{96}$

The following month the Labour Party pronounced strongly in favour of the government's recruiting campaign. In July the TUC announced its support of the "rabidly pro-war" Socialist National Defence Committee. ${ }^{97}$ The general perception that the unions were behind the war is correct. In defiance of majority opinion, it was as if NAFTA too was meant to save the honour of the British trade unionist.

Both Gossip and Bramley were longstanding ILP members, and Gossip had denounced the war from the very outset. There were also echoes of the democratic diplomacy of the UDC, on whose executive Bramley briefly sat as lone trade unionist towards the end of the war, and from whose platform he greeted the first Russian revolution..$^{98}$ Bramley was also observed attending a convention of the No Conscription Fellowship, again, according to Beatrice Webb, as the only representative trade unionist among the youthful war resisters. ${ }^{99}$ Despite these connections, there was more to the NAFTA manifesto than a precocious alignment with the "middle-class peace men". ${ }^{\circ 0}$ A confirmed trade-union internationalist, Gossip was an architect of the International Union of Woodworkers, which, through its secretary Theodor Leipart, sought to maintain its lines of communication during the war. There was also an immediate industrial aspect to NAFTA's anti-war stance, which was subsequently reaffirmed on issues like military and industrial conscription.

Bramley himself, though confessedly "bearing the reputation of a 'Pacifist", insisted on an "effective army and aggressive policy" in what he called the "real war" between workers and exploiters. ${ }^{\text {IOI }}$ Within the union, a strong stand was taken against the victimization of aliens, which certain sections distinctly favoured. ${ }^{102}$ Not every member was against the war, and the union contributed its fair share of volunteers for the forces. Nevertheless, while NAFTA's radicalism has been attributed to its unencumbered General Secretary, key decisions were in each case

96. NAFTA Monthly Report, March I9I 5, pp. 27-30, and May I9I 5, p. 2; also January i9i s, p. I4 for Bramley's first avowal of opposition to the war.

97. Bridgen, Labour Party and the Politics of War and Peace, p. 63.

98. The UDC, July 1917, p. 107 and December 191 8, p. 287.

99. Beatrice Webb diaries, entry for 8 April I916.

100. On which see Marvin Swartz, The Union of Democratic Control in British Politics during the First World War (Oxford, 197I), ch. 8.

Iог. NAFTA Monthly Report, March i916, pp. i I-i 2.

102. NAFTA Monthly Report, November 1914, p. I2, December 1914, p. I2, March I9Is, p. is. 
registered by a full membership ballot, even if the turnout was often unimpressive. ${ }^{103}$

There was a more basic sense in which Bramley's internationalism was rooted in his union values. In elaboration of his and Gossip's manifesto he published his first ever pamphlet, Class Cohesion Versus Spurious Patriotism. ${ }^{104}$ Conventionally, this presented the war as the product of commercial rivalries. Distinctively, it stressed the instinct of common interest displayed even now in the mutual regard and solicitude of Europe's warring rulers. As Bramley wrote unarguably, the "average British aristocrat" even now would sooner marry his daughter to a German Count than to a British bricklayer. Class went deeper than nation, and the purer class cohesion of the workers had to be reaffirmed against the spurious patriotism of union leaders and erstwhile class-war socialists like Hyndman. Bramley had a brother in the army and a son in the navy and he movingly described his "thrill of pleasure" at learning of the fraternization across the lines on the first Christmas of the war.

Within the UDC, Bridgen has distinguished between the four tendencies of UDC radicals, Gladstonian liberals, democratic socialists, and ILP pacifists. ${ }^{\text {Ios }}$ While Bramley had something in common with the first and last of these, his note of class solidarity cannot fully be assimilated to any of them. Like the Aberdonian audience when he held up his union card, he recalled the "spontaneous outburst of human feeling" when for the first time a German trade unionist, Carl Legien, addressed the TUC in I9I3. These were not issues "outside the province of Trade Union activity", and Bramley saw the unions as the vehicle of a democratic foreign policy to be realised by the "closer contact and clearer understanding" of the common people and in recognition of their entitlement to be consulted on any matter so manifestly concerning them.

The thinking that could justify the Anglo-Russian Committee is already apparent. So, in the rejection of "racial animosities", is the leniency of judgement that Bramley would extend to issues like the Bolshevik treatment of political prisoners. This was best demonstrated at the General Federation of Trade Unions (GFTU). It was characteristic of the British unions that, on the one hand, they were not divided on political or confessional lines, and, on the other, that there was some uncertainty as to which body represented their collective interest in its different aspects. Set up by the TUC itself, the GFTU had thus had some responsibility for solidarity issues and established a de facto precedence in matters of international representation. Bramley represented NAFTA at conferences of both bodies, and at the GFTU in I9Is he alone resisted a wave of indignation against German

I03. David Howell, MacDonald's Party: Labour Identities and Crisis (Oxford, 2002), p. 2 I 8.

I04. Bramley, Class Cohesion versus Spurious Patriotism.

I05. Bridgen, Labour Party and the Politics of War and Peace, ch. 4. 
atrocities, and urged that the unions should emphasize "points of agreement between the working classes of the different countries", not those arousing mutual hatred. ${ }^{106}$ As Jowett through the ILP and UDC expressed similar sentiments, and Bradford emerged as something of a UDC stronghold, it may be that familiarity with the city's sizeable German community helped inoculate against the worst of wartime bigotries. Pro-Germanism shared with pro-Bolshevism an instinctive aversion to atrocity stories, which some recent accounts suggest were better founded even in I9I4 than Bramley would ever have allowed. ${ }^{107}$

While Bramley thus upheld his union's anti-war and anti-coalition policies, his instincts of loyalty and a sort of conciliationism remained. When O'Grady complained of persecution within NAFTA, Bramley was specifically exempted from his criticism. ${ }^{108}$ Bramley also declined to condemn those carrying out any policy in a representative capacity, including even Arthur Henderson, who as minister in the wartime coalition was seen by many as complicit in the repression of working-class activists. Bramley not only moved the conciliating device, agreeable to Henderson, of an internal investigation of the matter. ${ }^{109} \mathrm{He}$ also maintained that, the Labour Party having agreed to its representatives serving in the government, "it was obviously unfair to persecute them". ${ }^{\text {II }}$

This respect for collective protocols was reciprocated by those, like Henderson himself, who did not wish to see the anti-war elements forced to the margins of the movement. It was thus in that same year, I9I5, that Bramley was first elected by congress to the TUC's parliamentary committee. Doubtless he was assisted by his cooperation in remitting an anti-war resolution whose provisions had already been discussed. ${ }^{\text {II }}$ Nevertheless, it is a striking indication of the unions' pluralistic culture, and two years later, though still in a distinct minority, Bramley applied successfully for the new full-time position of TUC Assistant Secretary. As he had justly observed a little while earlier, "a representative of a small union, though pleading from sometimes an unpopular cause, can depend on the tolerant support of Congress, providing on Trade Union matters responsibilities are faced and duties done". ${ }^{\text {I }}$

Bramley was also by this time chairman of the London Labour Party. In the immediate postwar general election, held in an atmosphere of

106. GFTU i6th General Council meeting, Report (London, I915), pp. I8-24.

107. John Horne and Alan Kramer, German Atrocities, I9I4: A History of Denial (New Haven, CT [etc.], 200I).

108. NAFTA Montbly Report, August 1917, pp. I8-19, and September 1917, p. I6.

109. Labour Party Conference, Report (London, 1917), pp. 89-90, 9I-94, I04-II I.

I I0. Labour Party Conference, Report (London, I918), p. 37.

I I I. 47th TUC, Report (London, I915), pp. 365, 404.

I I2. NAFTA Monthly Report, October 1916, p. I 8. 


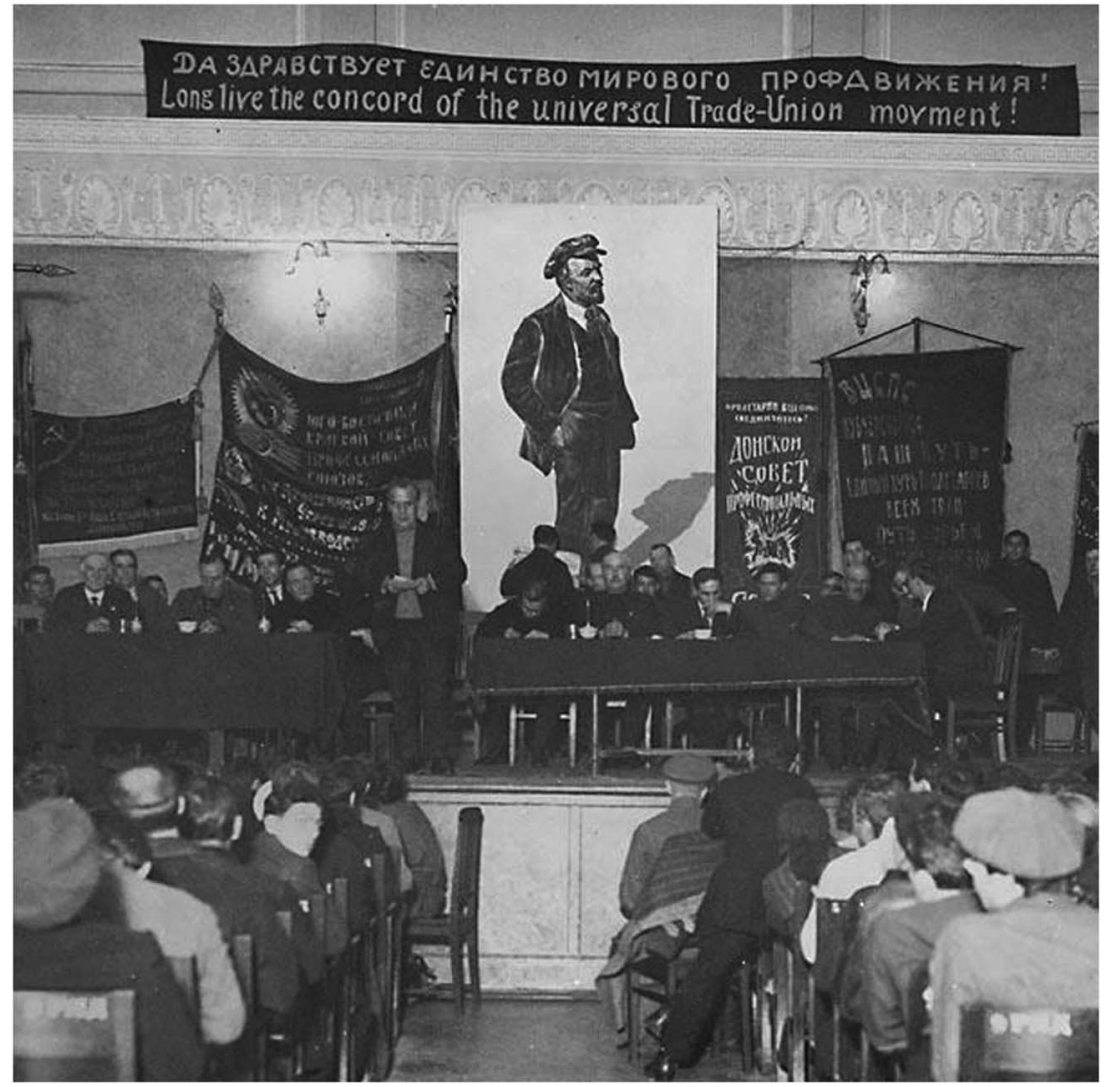

Figure 3. Fred Bramley addressing Russian trade-union delegates as Secretary of the TUC delegation to Russia, November-December 1924. A committed internationalist during World War I, in his final years Bramley's ideal of international "class cohesion" became focused on rapprochement with the Russian unions. Though this position was rejected by the TUC's counterparts in the rest of Europe, until after Bramley's death in 1925 it commanded general if sometimes half-hearted assent within the TUC itself. Seated to Bramley's right are (from left to right) his fellow delegates Herbert Smith (Miners), Alan Findlay (Patternmakers), the delegation chairman A.A. Purcell (Furnishing Trades), and Ben Tillett (Transport and General Workers). TUC Library Collections, London Metropolitan University. Used with permission.

retribution against the Germans and their friends in Britain, he fought intrepidly in a "highly personalised" campaign in the naval seat of Plymouth, where he was assailed as a "Bolshy, Pacifist, and Conchy". Ir 3 Defeated, like nearly every other candidate having merited those epithets, he was to relinquish his parliamentary ambitions definitively in I923 as a 
condition of becoming the TUC's first full-time Secretary. Bramley had only two years to live and his contribution at the TUC has rarely attracted much notice. Nevertheless, it was in just these two years that the TUC embarked upon its unexpected excursion with the Russians.

\section{TUC INTERNATIONALISM AND THE “RUSSIAN EXPERIMENT"”}

"Revolutionary Russian and stubborn, slow-moving Briton both call to the American worker": this was how the TUC report on Russia was advertised by the New York Daily Worker, which on its publication in I925 serialized all 250 pages. ${ }^{114}$ Delegations from other countries were to follow, but none had the TUC's official standing. Nor, on the other hand, were there any communists on the TUC general council, while the Communist Party in Britain was numerically one of Europe's weakest. ${ }^{\mathrm{II}}$ Four years earlier, the International, in relocating to the British capital, had described London and Moscow as the "two antagonistic forces [...] around which the socialist forces will crystallise". ${ }^{\text {I6 }}$ It was Bolshevism, moreover, which in the form of the disputed Russian treaties had been the issue that brought down the Labour government in the autumn of 1924. The publication of the forged Zinoviev letter had then featured in a frenzied campaign to mobilize opinion against any such Russian connection. ${ }^{117}$ No wonder Oudegeest found it perplexing that the TUC should embark upon it at just this time.

The notion of the relatively unencumbered officer as protagonist is clearly part of the explanation. If nothing else, the Bolsheviks seemed to act on this assumption in their cultivation of key leadership figures. That Lansbury, for example, should have enjoyed generous Soviet healthcare facilities on his visit in 1926 was a form of solidarity that was clearly not entirely disinterested on either side. ${ }^{118}$ Bramley's health was very much worse than Lansbury's, and though he was sent by his colleagues on a South America cruise, his deteriorating health was seen by his Russian counterpart Tomsky as imperilling the relations that had so laboriously been established. Tomsky wrote to him:

We are so few in number and the Cause we defend is so enormous, that our common task is to keep healthy and take good care of every honest and staunch fighter $[\ldots]$. The continuance of your illness and even the temporary abstinence

I 4. Daily Worker (New York), 28 July i925.

I I5. Fred Bramley in I92 I opposed its affiliation to the Labour Party as a "dangerous disruptive element”; Labour Party Conference, Report (London, I921), pp. 102-103.

i 16. Cited in Ward, Red Flag and Union Jack, pp. I 56-1 57.

I 17. On this see Andrew J. Williams, Labour and Russia: The Attitude of the Labour Party to the USSR (Manchester, I989), ch. I.

I 18. On this point see Morgan, Bolshevism, Syndicalism and the General Strike, pp. 179-180. 
from work may bring about great difficulties as the last meeting of the Committee proved beyond doubt. ${ }^{\text {I9 }}$

The intensification of such difficulties following Bramley's death was to underline just how important a role he had played in the liaison with Tomsky and his colleagues.

Even so, he has never since had such recognition as the Russians then accorded him. In accounts of the Anglo-Russian Committee he is not always mentioned at all. ${ }^{\mathrm{I} O}$ Nor has he had much credit for his wider contribution as the TUC's first full-time officer. Bramley's years in office were crucial ones in respect of the powers and prerogatives of the TUC General Council that replaced the Parliamentary Committee in I92I. With an eye to the solidarity issues that culminated in the 1926 General Strike, this is usually discussed in terms of central powers vis-à-vis the individual unions, on which point Bramley contributed little but a native sense of caution. ${ }^{\text {II I }}$ This may explain why Bramley is passed over in TUC histories like Martin's and Taylor's. Even in respect of its international commitments, it is Citrine who tends to be singled out as the exception to the presumed parochialism of his fellows. ${ }^{\text {I22 }}$ Nevertheless, there is no evidence in Citrine's autobiography that he held this wider outlook prior to his appointment as Bramley's assistant in 1924. In the maturing of Citrine's trade-union outlook, a formative debt to Bramley may need to be registered, just as Bramley was similarly indebted to Hartley.

Bramley had achieved high office as one who had demonstrated his respect for difference with an overall ethos of unity. Membership of a minor union assisted, as a mere cabinet-maker was above suspicion of pushing any overweening sectional interest. It was thus that in his election as TUC Secretary Bramley defeated candidates from several of the TUC's heavyweight unions. Relative industrial weakness was also conducive to a higher valuation of collective institutions, and it is interesting that Leipart, now Bramley's German counterpart, was another sometime woodworkers' official accredited by colleagues with an outlook ranging beyond the confines of his own industry. ${ }^{\mathrm{I2} 3}$ While mindful of these wider responsibilities, Bramley, on assuming his official responsibilities, had made claim to "freedom of initiative and some power to take action in matters of detail". ${ }^{24}$ It was a time for reconstruction, of the workers' movement as

I 19. Mikhail Tomsky to Fred Bramley, I9 September 1925, MRC 292/21/I2/I.

I 20. E.g. Williams, Labour and Russia, pp. 22-40.

I 2 I. See his comments on the extension of the TUC's prerogatives in Bramley, "Impressions of the Scarborough Trades Union Congress", p. 247.

I 22. E.g. Howe, "Labour and International Affairs", p. I 27.

I23. Gerard Braunthal, Socialist Labor and Politics in Germany: The General Federation of German Trade Unions (Hamden, CT, 1978), pp. 95-96.

I 24. Fred Bramley, “Office Development. Supplementary Statement”, n.d., I9I 8, MRC 292/28/1. 
well as Europe as a whole, and it was in an international context that the scope for initiative was most clearly demonstrated.

In the first instance, it meant the assertion of TUC prerogatives against the GFTU. Prior to the war the TUC had ceded precedence in matters of international representation and in I9I9 the GFTU secretary W.A. Appleton had assumed the presidency of the relaunched IFTU. It was Bramley who at this time proposed a TUC International Bureau, and with the establishment of such a department the following year Appleton gave way to the Railwaymen's leader J.H. Thomas as IFTU president. ${ }^{\text {I25 }}$ With the creation at this same time of a national Labour Party apparatus under Henderson's direction, a prospect of seamless cooperation between Labour and the TUC was seemingly opened with the establishment of joint departments in I92I. One of the departments dealt with international affairs, while the TUC's International Trades Union Review, also established under Bramley's aegis, gave way the following year to the jointly sponsored Labour Magazine.

Bramley least of all, on the face of it, should have had concerns about a single homogeneous movement such as he had known in Bradford. Indeed, in I92 I he loyally propounded the "wise co-ordination" of voting strength, spending power, and industrial solidarity, and thus a "triple alliance", not of the unions themselves, but between the unions, party, and cooperatives. ${ }^{\mathrm{I} 26}$ Despite its assumption of a leading role within IFTU, as late as the LSI's founding conference at Hamburg in May 1923, the TUC continued with its anomalous inclusion within the British delegation. When the first Labour government was formed the following January, Bramley was to assure the Russians that its ministers were not the masters of the trade-union movement, but their servants. ${ }^{127}$

It was the hollowness of such a claim that saw the TUC seek to reassert its independence. The inclusion in MacDonald's government of the moderate trade unionists Thomas and Margaret Bondfield created vacancies as TUC Chairman and IFTU President, both of which were filled by Bramley's NAFTA comrade, Purcell. Though himself a Labour MP, Purcell retained a syndicalist's disregard for party authority and would have had no reason to dispel Bramley's outright frustration at MacDonald's failure ever to meet him. ${ }^{\text {I28 }}$ Though Purcell's TUC chairmanship ended in September 1924, he was succeeded by a fellow "left", Alonzo Swales, and himself remained

I 25. Idem, "International Bureau", memo presented to TUC parliamentary office committee, I6 May I9I9, MRC 292/28/I.

I26. Idem, "The British Trades Union Congress and General Council", International Trade Union Movement, October I921, p. I60.

127. Idem in M. Tomsky, Getting Together: Speeches Delivered in Russia and England 1924-I925 (London, I925), p. 39.

I28. “Mr Bramley’s Points re Joint Departments”, n.d. but I925, MRC 292/28/r. 
another year as Vice-Chairman. By this time Bramley and Henderson, though occupying adjacent buildings, were said to be "hardly on speaking terms", and Bramley now pushed for the recovery of the TUC's "distinctly separate" public profile and identity. ${ }^{\mathrm{I2}}$ It was not until the TUC assembled again in September I925 that the General Council resumed control of its own research, publicity, and international departments. ${ }^{130}$ But already the previous year, the exclusively trade-union composition of the TUC's Russian party offered a signal contrast with the joint delegation it had sent with the Labour Party four years earlier. ${ }^{\mathrm{I} I}$

There was therefore something in Pollak's view that the Russian report represented a reaction against the Labour government on the part of trade-union "bosses". ${ }^{32}$ One should not be surprised at these union-party tensions, which at just this time were also clearly evident in the German movement. ${ }^{\mathrm{I} 3}$ It is not so immediately obvious why Russia should have occasioned the most conspicuous display of the TUC's new-found assertiveness. In explaining the delegation's rationale, Bramley touched on issues regarding the rights of Russian unions that were clearly germane to the TUC's IFTU commitments. ${ }^{134}$ On the other hand, in taking upon itself to investigate the Zinoviev letter, towards which MacDonald's response had attracted so much criticism, it encroached more directly on party affairs; and in the authoritative appearance of the report itself, which extended to all aspects of Soviet rule and was explicitly modelled on official precedents, it marked the TUC's incursion on to prerogatives traditionally exercised by the state and political establishment. ${ }^{\mathrm{I} 35}$

The two strands of Bramley's biography indicate possible explanations. On the one hand, an extenuating pro-Bolshevism had become a sort of political litmus test for the currents of internationalism with which Bramley had become identified. Through the adhesion of former Liberals like E.D. Morel and H.N. Brailsford, a UDC influence was strongly felt within the post-war Labour Party. At the LSI's Hamburg conference it was thus Brailsford who, on behalf of a united British delegation, had resisted the issuing of a resolution condemning the Soviet Union. ${ }^{136}$

I 29. Beatrice Webb diaries, entry for 2 October 1925; "Mr Bramley's Points".

I30. 57th TUC Report (London, 1925), pp. 356-369.

I 3 I. For which see Stephen White, "British Labour in Soviet Russia, 1920", English Historical Review, I 3 (1994), pp. 62 I-640; Morgan, Bolshevism, Syndicalism and the General Strike, ch. 3.2. I32. Oscar Pollak, "Amsterdam, Moscow and England", trans. from Arbeit und Wirtschaft in Bramley papers, box I.

133. Braunthal, Socialist Labor, pp. I23-1 27.

134. Daily Herald, 6 November 1924.

I35. TUC, Russia: The Official Report of the British Trades Union Delegation to Russia and Caucasia Nov. and Dec. 1924 (London, I925), p. xxiii.

136. Bruno Naarden, Socialist Europe and Revolutionary Russia: Perception and Prejudice I848-I923 (Cambridge, I992), pp. 509-5I4. 
The potential for cooperation between trade unionists and UDCers was again to be demonstrated during the Labour government. When in April I924 a Russian delegation arrived in London for the trade negotiations, it was Bramley who at the welcoming dinner proposed a continuous contact with the TUC and indicated the readiness of the latter to lend its assistance in the event of any obstructions. When Tomsky then addressed the TUC, and was greeted with "the greatest éclat ever known" at such a conference, Bramley must once again have been reminded of Legien's earlier appearance as fraternal delegate. ${ }^{\mathrm{I}} 37$ When the treaty negotiations did for a time seem in jeopardy, it was Purcell and the UDCer Morel who publicly intervened, in what Purcell described as an act of "real open diplomacy [...] promoted by the working classes". ${ }^{138}$ Though Morel died just a few weeks later, the UDC connection was continued by George Young, like Morel a bitter critic of the MacDonald government, who acted as chief adviser to the TUC Russian delegation and authored large sections of its report. ${ }^{\text {I }}{ }^{39}$

If internationalism was a defining strand, there were plenty of internationalists who did not project it on to Soviet Russia. The other distinctive feature of Bramley's biography, its socialist latitudinarianism, was therefore equally important. In defending the Russian delegation before its critics within IFTU, Bramley rejected anti-Bolshevik caricatures and what he saw as irrational impulses of hostility. Just as during the war, he insisted instead on the search for what united rather than what divided. His presentation of the argument was an overtly relativizing one. Thus, he urged recognition of differences of "race", tradition, and (most importantly) economic and political circumstance, while reaffirming his conviction that communism was as little required in Britain as it was inevitable in Russia. ${ }^{10}$

Despite this much-repeated caveat, there is no doubt that Bramley was as powerfully impressed by apparent commonalities of basic object as he was by differences in method. Three years earlier he had looked to the speedy dissolution of a rotten capitalist system that remained in existence "only because of the disunity, indifference, and inefficiency of the workers". ${ }^{\mathrm{I} I}$ These at least were not criticisms that could be levelled at the Bolsheviks. "There is no doubt about the workers being in possession", Bramley wrote shortly after his arrival in Russia. "The Red Flag predominates everywhere [...] and the Dictation of the Proletariat is complete." ${ }^{42}$ Addressing the Russian unions, he outlined British Labour's three-pronged attack on

I37. J.T. Walton Newbold to Ramsay MacDonald, n.d. but 1927, National Archives 30/69 I 172.

138. Coventry Herald, 3-4 October 1924.

139. For Young see Morgan, Bolshevism, Syndicalism and the General Strike, pp. 132-1 33 .

I40. Report of IFTU general council, 6-7 February i925.

I4I. Bramley, "British Trades Union Congress and General Council".

I42. Fred Bramley to Walter Citrine, I3 and I6 November I924, MRC 292/21.I2/I. 
capitalism through its political, industrial, and cooperative organizations. ${ }^{43}$ Exactly the same motif reappeared in the delegation's report, but this time in relation to the "threefold democracy" of soviets, unions, and cooperatives through which the Bolsheviks themselves had set about the building of a different social order. ${ }^{\text {I4 }}$ The Webbian derivation of such an argument is unmistakeable. Like his near-contemporary Henry May, the Secretary of the International Cooperative Alliance, Bramley projected onto NEP-era Bolshevism a Webbian idea of multiform democracy some several years before the Webbs themselves announced its altogether more fantastical realization with the onset of Stalin's "iron age". ${ }^{.45}$

Bramley's last major platform appearance was at the militant Scarborough TUC in September I925. Here he took particular satisfaction in a strongly worded declaration against imperialism moved for NAFTA by Purcell. Typically, Bramley described it as "the considered view of organised labour for many years", and linked it with the apparently more prosaic demand for international labour standards as the alternative to industrial protectionism. ${ }^{46}$ His own principal contribution was a forthright defence of the TUC's Russian policy. According to its particular national circumstances, he again presented the Russian revolution as "the first great national experiment of working-class control, giving expression [...] to the resolutions we have passed at Trades Union Congresses for many years". He also noted how, while those who had launched world wars were restored to the comity of nations, the breach in capitalism alone received the "universal condemnation without racial distinction, of the possessing and exploiting class of Europe". ${ }^{147}$ Class cohesion on the one hand; spurious distractions on the other: the communist J.T. Murphy, describing this as Bramley's valediction to the movement, was reminded of his Clarion days and the discovery in Russia of "the lineaments of the things he had dreamed of and propagated in his youth". ${ }^{148}$ There was no time now to suffer disillusionment. Four weeks later, aged just fifty-one, Bramley died in his sleep while attending to IFTU business in Amsterdam.

There is a voluminous file of tributes in the TUC archives. ${ }^{149}$ The stylized encomiums of the "Georgian proletariat" recall how the TUC's support for the suppression of the Georgian Mensheviks had struck Adler

I43. Inprecorr, I6 December I924, p. 978.

I44. TUC, Russia, pp. I39, I70.

145. For May and the Webbs, see Morgan, Webbs and Soviet Communism, pp. 193-198 and passim.

I46. Bramley, "Impressions of the Scarborough Trades Union Congress", pp. 246-8.

I47. 57th TUC Report (London, I925), pp. 483-484.

I48. J.T. Murphy, New Horizons (London, I94I), p. 206.

I49. MRC 292/21.I2/3. 
and many others as particularly scandalous. Those of the paramilitary Roter Frontkämpferbund, with which Bramley had so little in common, are suggestive of the internationally co-ordinated nature of the communist campaign around trade-union unity. So too, therefore, are the more personalized communications of the British communists Pollitt and Inkpin; but these also evoke a common socialization in an as yet undivided movement, and Pollitt in his autobiography was to tell of how he once secured an audience with Bramley through the reminder of a pre-war Clarion meet. ${ }^{\mathrm{I}}{ }^{\mathrm{O}}$

Citrine, as Bramley's successor, had few such resources of memory and association with which to offset the logic of institutional division. To this extent, Bramley was like a survival from an earlier age of socialist pluralism, and his promotion of a discourse of unity appears as an unavailing effort to extend this to labour-movement cultures that had always been more deeply marked by faction. To movements now defined by the split with communism, this mainly came across as a sort of innocence or naivety, though for some it also offered the glimpse of an alternative. Edo Fimmen, the left-wing Secretary of the International Transportworkers' Federation, was one. As Bramley's body was transported back to Britain, he described how "for the first time in the history of the Dutch trade union movement Socialists, Communists and Syndicalists marched together in the same procession [...] about a quarter of a mile long that followed [the] coffin to the station". Only those who knew the mutual hatred of these groupings, Fimmen went on, could appreciate what the demonstration meant. ${ }^{\text {ISI }}$ Momentarily, but only momentarily, it was as if the Clarion van had moved onto a wider stage.

Caught within the arbitrary parameters of the individual life, Bramley cannot take us beyond this moment of only seeming unity. If this is the limitation of biography, the same arbitrary timespan nevertheless offers insight into patterns of belief and association which, in a shallow chronology or purely institutional perspective, are all too often overlooked. A life like Bramley's does not only register personality and caprice. It can also reveal the complex sociality of the individual by whom competing forms of collective identity were articulated, assisted in this instance by the pluralistic culture which the British unions reconciled with their strong ethos of unity. Bramley was not an unencumbered agent. At the time of his greatest influence, as full-time secretary of the TUC, he was constrained at once by his responsibilities to those who employed him, by the vagaries of the TUC's leading personnel, and by its complex and shifting relations both with its constituent unions and with the Labour Party.

I 50. Harry Pollitt, Serving My Time (London, I94 I edn), p. 5 I.

I 5 I. Edo Fimmen to Walter Citrine, 26 October 1925, MRC 292/21.I2/3. 
Nevertheless, Bramley also enjoyed some manifest scope for initiative, particularly when, somewhat fortuitously, his NAFTA colleague Purcell assumed temporary occupancy of the TUC's other highest office. As Pollak recognized, the movement in which Bramley and Purcell came to the fore was not only heterogeneous in character, but had not as yet excluded its heterodox elements from the institutional footholds from which to speak on its collective behalf. That in 1924-1925 Bramley and Purcell occupied the most important of these footholds is not the sole explanation of the TUC's mésalliance with the Russians. Nor, on the other hand, is any satisfactory explanation conceivable that overlooks it.

\author{
TRANSLATED ABSTRACTS \\ FRENCH - GERMAN - SPANISH
}

Kevin Morgan. Cohésion de classe et internationalisme ouvrier : Fred Bramley, le TUC britannique et l'Anglo-Russian Advisory Council (Conseil Consultatif anglo-russe).

Une image répandue du mouvement syndical britannique est qu'il était insulaire et lent à évoluer. L'Anglo-Russian Advisory Council du milieu des années I 920 est un épisode apparemment difficile à réconcilier avec ce point de vue. En l'absence, jusqu'à ce jour, de toute explication entièrement satisfaisante de cette gestation, cet article aborde la question bibliographiquement, par l'intermédiaire du premier secrétaire à plein temps du TUC, Fred Bramley (1874-1925). Les thèmes qui se dégagent nettement de la plus longue histoire de Bramley en tant qu'activiste ouvrier sont premièrement, une conception résolument latitudinaire du Mouvement ouvrier et deuxièmement, un internationalisme ouvertement ouvrier qui était profondément enraciné dans l'expérience syndicale de Bramley. Combinant ces engagements dans la forme d'un internationalisme syndical global, Bramley eut en 1924-1925 le soutien indispensable du président du TUC, A.A. Purcell qui, comme lui, était un ancien organisateur dans l'association limitée mais de militance internationaliste des Métiers de l'ameublement. Bramley étant décédé précocement et Purcell marginalisé, le Comité anglo-russe est finalement resté un épisode très irrégulier dans l'histoire de l'entre-deux-guerres du TUC.

Traduction: Christine Krätke-Plard

Kevin Morgan. Klassenzusammenhalt und gewerkschaftlicher Internationalismus: Fred Bramley, die britische TUC und der Anglo-Russian Advisory Council (English-Russische Beirat).

Die britische Gewerkschaftsbewegung wird weitgehend als insular und lethargisch wahrgenommen. Der in den I $920 e r$ Jahren aktive Englisch-Russische Beirat ist eine Episode, die sich nur schwer mit dieser Ansicht vereinbaren lässt. Eine ausnahmslos adäquate Erklärung seiner Entstehung steht bis heute aus; in Ermangelung ihrer wählt dieser Aufsatz eine biografische Herangehensweise und konzentriert sich auf den ersten Vollzeit-Sekretär des TUC, Fred Bramley (1874-1925). Zwei Themen, die 
in Bramleys umfassenderem Werdegang als Aktivist der Arbeiterbewegung eine starke Rolle spielen, sind zum einen seine ausgesprochen weite Auffassung von der Arbeiterbewegung und zum anderen ein unverhohlener Arbeiter-Internationalismus, der tief verwurzelt war in den von Bramley als Gewerkschafter gesammelten Erfahrungen. Indem er diese zwei Anliegen in einem inklusiven gewerkschaftlichen Internationalismus verband, erhielt Bramley $1924 / 25$ die unverzichtbare Unterstützung des TUC-Vorsitzenden A. A. Purcell, der wie Bramley selbst im kleinen aber militant internationalistischen Möbelhandwerksverband als Organizer tätig gewesen war. Infolge von Bramleys frühem Tod und der Marginalisierung Purcells sollte der Englisch-Russische Beirat innerhalb der Zwischenkriegsgeschichte des TUC eine weitgehend anormale Episode bleiben.

Übersetzung: Max Henninger

Kevin Morgan. Cohesión de clases e internacionalismo syndical: Fred Bramley, el TUC británico y el Anglo-Russian Advisory Council (Consejo Asesor Anglo-ruso).

Una de las imágenes que prevalecen del movimiento sindical británico radica en su carácter de aislamiento insular y en sus lentas dinámicas. El Consejo Asesor Angloruso que se instaura a mediados de la década de 1920 es un episodio que difícilmente se reconcilia con esta perspectiva. Dado que hasta la fecha no contamos con una adecuada explicación sobre su gestación, este artículo se aproxima al tema desde la biografía, a través del primer Secretario del TUC a tiempo completo Fred Bramley (1874-1925). Los temas que surgen de la larga historia de Bramley como activista sindical son, primero, una concepción pronunciadamente latitudinaria del movimiento obrero y, en Segundo lugar, un sincero internacionalismo proletario profundamente arraigado en la propia experiencia sindical de Bramley. Combinando este tipo de compromisos en la forma de un internacionalismo sindical inclusivo, Bramley contó, hacia 1924-1925, con el indispensable apoyo del Presidente del TUC, A.A. Purcell, quien como él había sido con anterioridad delegado en la reducida pero de tradición internacionalista militante Asociación Sindical del Mueble. Con el fallecimiento temprano de Bramley y la marginación de Purcell, el comité anglo-ruso ha quedado en gran parte como un episodio anómalo de la historia del TUC en el periodo de entreguerras.

Traducción: Vicent Sanz Rozalén 